\title{
Novelties from a cave lace bug (Heteroptera, Tingidae): first nymphal description with a discussion on the morphological patterns of Vianaidinae immatures
}

\author{
Marcus Guidoti ${ }^{1}$, Aline Barcellos ${ }^{2}$ \& Rodrigo L. Ferreira ${ }^{3}$ \\ 1. Programa de Pós-Graduação em Biologia Animal, Universidade Federal do Rio Grande do Sul, Departamento de Zoologia, Av. Bento Gonçalves, $9500,91501-970$ Porto Alegre, RS, Brazil. \\ (marcus.guidoti@gmail.com) \\ 2. Museu de Ciências Naturais, Fundação Zoobotânica do Rio Grande do Sul, Rua Dr. Salvador França, 1427, 90690-000 Porto Alegre, RS, Brazil. (alinebar.fzb@gmail.com) \\ 3. Centro de Estudos em Biologia Subterrânea, Departamento de Biologia, Universidade Federal de Lavras, 37200-000 Lavras, MG, Brazil. (drops@dbi.ufla.br)
}

\begin{abstract}
A nymph of Thaumamannia Drake \& Davis, 1960, a rare vianaidine genus known only from adults, is described by the first time. The specimens were collected in the soil and walls of caves located in the state of Pará, Brazil. This is the first record of Vianaidinae for Brazil. The T. vanderdrifti fifth instar is compared with the same stadium of Anommatocoris coleopteratus (Kormilev, 1955), the only other vianaidine nymph described so far, and patterns between them and within the family are also discussed.
\end{abstract}

KEYWORDS. Brazil, immatures, Neotropical, Thaumamannia.

RESUMO. Novidades de um tingídeo de caverna (Heteroptera, Tingidae): primeira descrição ninfal com uma discussão sobre os padrões morfológicos de imaturos de Vianaidinae. Uma ninfa de Thaumamannia Drake \& Davis, 1960, um raro gênero vianaidíneo conhecido somente pelos adultos, é descrita pela primeira vez. Os espécimes foram coletados no solo e em paredes de cavernas localizadas no Estado do Pará, Brasil. Este é o primeiro registro da subfamília para o Brasil. Esta ninfa, de quinto instar, é comparada com o mesmo instar de Anommatocoris coleopteratus (Kormilev, 1955), até então a única conhecida de Vianaidinae, e os padrões entre ambas as espécies e dentro da família são também discutidos.

PALAVRAS-CHAVE. Brasil, imaturos, Neotropical, Thaumamannia.

Vianaidinae is a small subfamily composed by six extant and two fossil species. All the extant species are from South America, and both fossil taxa were described from New Jersey's Cretaceous amber (Drake \& RuHofF, 1965; Golub \& Popov, 2000, 2003; Schun et al., 2006; Montemayor \& CARPINTERo, 2007). One of these fossil species had its placement within the subfamily discussed recently (SснUн et al., 2006). Two of the extant species were described from macropterous specimens ( $\mathrm{S}$ CHUH et al., 2006; Montemayor \& CArpintero, 2007), and the others from coleopteroid ones, usually collected in soil and associated with ant nests (DRAKE \& RuHOFF, 1965). There are two genera with coleopteroid forms: Anommatocoris China, 1945 and Thaumamannia Drake \& Davis, 1960. Thaumamannia is an exclusive coleopteroid genus, including two species: T. manni Drake \& Davis, 1960 and T. vanderdrifti Doesburg, 1977, from Bolivia and Suriname, respectively.

Thaumamannia vanderdrifti Doesburg, 1977 was described from specimens found in soil samples (DOESBURG, 1977). To our knowledge, this was the only sample of $T$. vanderdrifti obtained thus far. It differs from its congener by the pronotum, deeply punctuate and posteriorly rounded; costal area narrower anteriorly, longer carina-like vein elevation on the hemelytra; and by the lateral branch of metasternal scent gland, extending far beyond the hemelytra (Drake \& Davis, 1960; Doesburg, 1977). Besides the description of both genres for this species, no information regarding the immatures was provided. The species was well-illustrated despite some incongruences between the illustrations and description (DOESBURG, 1977). In addition, there is no information about the nymphs of T. manni as well.

Tingidae immatures, specially nymphs, were recently target of evolutionary studies and phylogenetic analyses (Guilbert, 2004; GuilBert et al., 2008). It is believed that the remarkable morphology of the exaggerated outgrowths of some lace bugs nymphs has evolved from simple to complex in a similar pattern observed in the adult morphology (GUILBERT, 2004). Regardless the importance of immature descriptions, contributions about this life stage in Tingidae are not very common, especially when all the stadia are considered (GUIDOTI \& BARCELLOS, 2013). The only vianaidine with immatures described so far is Anommatocoris coleopteratus (Kormilev, 1955). However, only the fifth nymph was described for this species, although measurements are available for third and fourth stadia. An illustration of $A$. coleopteratus fifth stadium is also available (DraKe \& DAVIS, 1960).

We described here the fifth instar of Thaumamannia discussing its morphology within the family. Hypotheses regarding adaptative traits are proposed. In addition, the first record of the subfamily for Brazil is presented. This constitutes the first nymphal description for Vianadinae illustrated with SEM images.

\section{MATERIAL AND METHODS}

Study area. The caves in which the specimens were observed are located in two interconnected ferruginous 

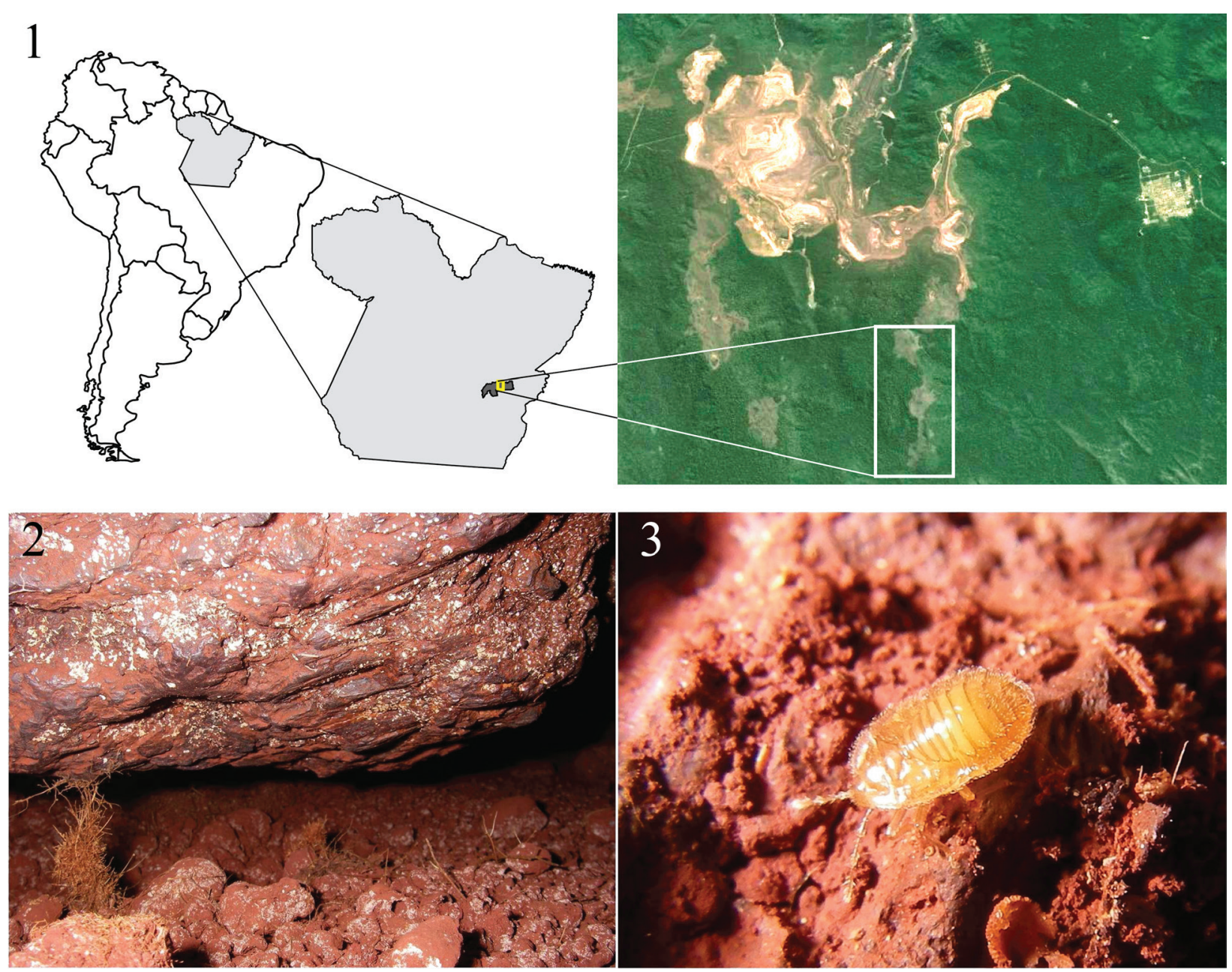

Figs 1-3. Sampling site of Thaumamannia vanderdrifti Doesburg, 1977 in Parauapebas, state of Pará, Brazil: 1, schematic location map; 2, iron ore in a cave wall; $3, T$. vanderdrifiti, fifth instar in the cave floor.

outcrops situated in Parauapebas municipality (state of Pará, northern Brazil; Fig. 1). Such outcrops are inserted in a protected area (Floresta Nacional de Carajás), although they are threatened by mineral exploitation (for the extraction of iron ore).

Collection and preservation. Specimens were collected during 2010 and 2011 and are deposited in the Zoology Collection, Seção de Invertebrados Subterrâneos (ISLA) at the Universidade Federal de Lavras (UFLA), Campus Universitário de Lavras, Minas Gerais, Brazil. Specimens were visualized throughout the floors and walls of the caves (Figs 2,3), captured with a fine brush and placed into vials with $70 \%$ ethanol. Special attention was also paid to decaying vegetation (e.g., leaves and tree bark) and animal carcasses, although this material was only common near the cave entrances. Fourty-seven individuals were observed (although just a few were collected: three fifth stadium nymphs and three adult males) in 22 caves - GEM-117, GEM-1195, GEM-1645, GEM-1646, GEM1694, GEM-1701, GEM-1707, GEM-1709, GEM-1717, GEM-1719, GEM-1721, GEM-1727, GEM-1734, GEM1735, GEM-1744, GEM-1753, GEM-1755, GEM-1757, GEM-1760, GEM-1770, GEM-1789, GEM-1799).
Specimens treatment. Photographs were taken with a digital camera attached to a microscope. Specimens were dried with critical point and gold coated for SEM analysis. Measurements were obtained from three specimens with a measuring reticle attached to the eyepiece, here presented in millimeters as mean (minimum - maximum). The body width was measured at the middle line of pronotum. The terminology followed GUILBERT (2005).

\section{RESULTS}

\section{Thaumamannia vanderdrifti Doesburg, 1977}

Fifth stadium. Ovoid, reddish brown (Fig. 4). Strongly convex dorsally, slightly lesser ventrally. Tegument shiny, dorsally and laterally covered with dense pubescence, less dense in ventral surface (Fig. 5). Thoracic and abdominal margins serrate (Fig. 6).

Head sligthly longer than wide. Eyes prominent, bearing about three omatidia. Clypeus well developed, much longer than juga. Lateral margins of juga convex, slightly angled near apices; these rounded. Antenniferous tubercles well developed. Antennal segments pubescent, increasing 

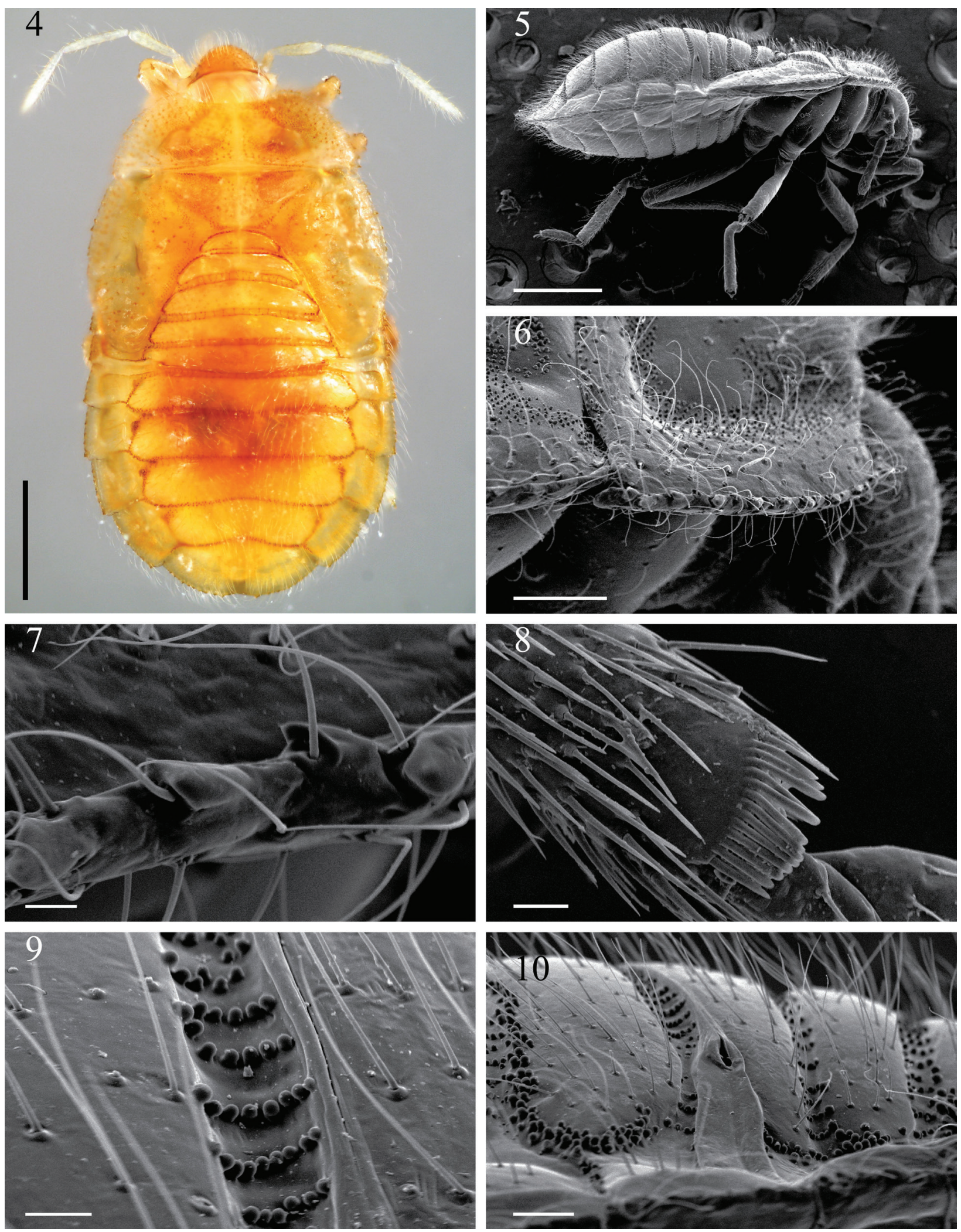

Figs 4-10. Fifth stadium nymph of Thaumamannia vanderdrifti Doesburg, 1977: 4, dorsal habitus; 5, lateral view; 6, thoracic margin; 7, scale-like integumentary projections; 8 , tibial combs in foreleg; 9 , small rounded granular projections in the urotergites intersegmentary membrane; 10 , scent gland opening. Scale bars: 4, $0.5 \mathrm{~mm} ; 5,500 \mu \mathrm{m} ; 6,100 \mu \mathrm{m} ; 7,10 \mu \mathrm{m} ; 8-9,20 \mu \mathrm{m} ; 10,50 \mu \mathrm{m}$. 
in length towards fourth; scape about half of the pedicel, not surpassing apex of head; pedicel, basiflagellomere and distiflagellomere slightly different in size. Rostrum almost reaching posterior margin of third urosternite.

Pronotum about three times wider than long; anterior and lateral margins convex; posterior margin sub-rectilinear. Lateral margins bearing scale-like integumentary projections (Fig. 7). Small rounded granular projections distributed throughout pro- and mesonotum. Pronotal scars darker and depressed. Wing pads reaching the limit between third and fourth urotergite. Metanotum small, almost half the width of first urotergite; similar in aspect to the abdominal tergites. Legs pubescent; longer hairs scattered among shorter ones along outer margin; coxae conical, projected ventrally. Tibial combs (Fig. 8) present in all legs. First tarsomere very short, about one fourth the length of the second. Claws well-developed. Spiracles present on pro- and mesopleura. A scar present in metapleura, in the same region of the adult metathoracic gland. Pro- and mesopleura bearing the same small rounded granular projections than the pro- and mesonotos, these absent in metapleura.

Nine shiny, strongly esclerotized urotergites visible; intersegmental membrane bearing transversal lines composed by small rounded granular projections (Fig. 9). Lateral margins with integumentary projections as those of the thorax. Scent glands openings present laterally in the posterior region of fourth urotergite, followed by a large evaporatory area free of projections (Fig. 10). Connexivum well delimited dorsally. Ventrally, nine segments are distinguished. Spiracles visible on sternites II-VIII.

Measurements. Body length, 2.33 (2.29 - 2.36); body width, 1.17 (1.12 - 1.25); head length, 0.23 (0.22 $0.25)$; head width, $0.42(0.41-0.44)$; pronotum length, 0.33 (0.32 - 0.34); wing pad length, 0.77 (0.76-0.79); scape length, 0.09 (0.08-0.11); pedicel length, 0.23; basiflagellomere length, $0.33(0.31-0.36)$; distiflagellomere length, $0.37(0.36-0.39)$.

\section{DISCUSSION}

The caves where the specimens were collected are associated to the superficial ferruginous breccia (canga formation). Although considered "macro" caves, most of those cavities are small, with sizes varying from 8 meters (GEM 117) to 204 meters (GEM 1727) (mean $\pm \mathrm{SD}$ corresponding to $70.38 \pm 55.28 \mathrm{~m}$ ). However, all of those caves are connected to a large network of small channels (canaliculi), typically found in the canga formation, which considerably increases the habitats for the subterranean fauna in iron ore caves (SouzA-Silva et al., 2011). Accordingly, it is possible that specimens migrate between caves by sub-superficial voids. The position of specimens inside each cave was quite variable. In some caves, individuals were found near the entrance while in others in deeper areas. It suggests a lack of preference for specific conditions of temperature, light and moisture inside the caves. This could be also supported by the fact that these caves possess distinct morphologies and dimensions, so those factors seem not to be relevant to determine species preferences. Individuals were found under fallen rocks on the floor or associated to roots aggregations that grow in different parts of the caves. Most of the specimens ( 32 from 47) were observed in the dry season, what could indicate that the association to caves is eventually related to a search for moist habitats. Unfortunately, no interactions were observed between $T$. vanderdrifti and any other species.

Considering Tingidae nymphal morphology, the fifth instar here described shares several traits with the other vianaidine nymph known thus far. However, the brief description available for the $A$. coleopteratus nymph (Kormilev, 1955), and the only illustration provided (DrAKE \& DAVIS, 1960), hamper the comparison between these species. The absence of detailed and illustrated descriptions plays a major role as an impediment for further comparisons and establishment of homology hypotheses on Tingidae immatures (Guidoti \& BARCELLOS, 2013). Nevertheless, the position of the scent glands opening, the scape not surpassing the apex of clypeus and the absence of cephalic, abdominal and thoracic (both lateral and dorsal) tubercles are the most remarkable features presented by both $T$. vanderdrifti and $A$. coleopteratus nymphs. Although there are some genera within Tingidae which have nymphs without any tubercle (e. g., Atheas insignis Heidmann, 1909 - Guilbert, 2005) and some with short scape (Dictyonota strichnocera Fieber, 1844 - GUILBERT, 2004), the position of the scent gland opening seems to be an unique character for vianaidines within Tingidae.

The exaggerated outgrowths of Tingidae nymphs, such as the lateral and dorsal tubercles aforementioned, are associated with chemical communication and chemical and physical protection (LivingSTONE, 1976; AldRICH et al., 1991; Mason et al., 1991). The habitat of T. vanderdrifti, as well as of all coleopteroid species of Vianaidinae, justifies the barely developed compound eyes of both nymphs and adults. The lack of the visual perception of their surroundings could be a positive pressure for a complex scenario of chemical communication. Thereby, the absence of those tubercles is interesting. The body colour, similar to the cave soil, may be an effective camouflage strategy that meets the species needs regarding predation protection. In addition, the uncommon large evaporatory area for Tingidae nymphs could be associated with potentialized effectivity of the abdominal scent glands products (SCHUH \& SLATER, 1995). Therefore, the lack of the protective properties of the exaggerated outgrowths absent in this nymph could be supplied by the body camouflage and a higher scent gland activity. These hypotheses are based exclusively in the morphology here described, and thus, deserve further supporting.

More data on Tingidae immatures, particularly on vianaidines, are very important to the understanding of morphological patterns here highlighted, as well as for phylogenetic analyses on the evolutionary trends and 
relationships among the family taxa. Well-illustrated contributions may provide enough data for further and more comprehensive studies. The knowledge on all nymphal stadia could bring important informations on the ontogenetic steps of species development, and these can reveal new homologies between vianaidines and within lace bugs.

Acknowledgements. We thank Augusto Ferrari, for allowing the use of SEM equipment and to Kim Barão for helping in its operation. To CNPq (Brazil) for the first author's master degree fellowship and for funding RLF (CNPq grant 301061/2011-4).

\section{REFERENCES}

Aldrich, J. R.; Neal, J. W.; Oliver, J. E. \& Lusby, W. R. 1991. Chemistry vis-à-vis maternalism in lace bugs (Heteroptera: Tingidae): alarm pheromones and exudate defense in Corythucha and Gargaphia species. Journal of Chemical Ecology 17(11):2307-2323.

Doesburg, P. H. 1977. A new species of Thaumamannia from Surinam (Heteroptera, Tingidae, Vianaidinae). Zoologische Medelingen 52(14): 187-189.

DrAKE, C. J. \& DAVIS, N. T. 1960. The morphology, phylogeny, and higher classification of the Family Tingidae, including the description of a new genus and species of the subfamily Vianaidinae (Hemiptera: Heteroptera). Entomologica Americana 39:1-100.

Drake, C. J. \& Ruhoff, F. A. 1965. Lacebugs of the World: a catalog (Hemiptera: Tingidae). United States National Museum Bulletin 243:1-634.

Golub, V. B. \& Popov, Y. A. 2000. A remarkable fossil lace bug from Upper Cretaceous New Jersey Amber (Heteroptera: Tingoidea, Vianaididae), with some phylogenetic commentary. In: GRIMALDI, D. A. ed. Studies on fossils in amber, with particular reference to the Cretaceous of New Jersey. Leiden, Backhuys, p. 231-239. 2003. The new fossil genus of Vianaididae (Heteroptera: Tingoidea) from the Cretaceous amber of New Jersey; evolution of the family in the Late Cretaceous. Acta Zoologica Cracoviensia 46(suppl.):109-116.
Guidoti, M. \& Barcellos, A. 2013. On the nymphs of lantana lace bug Teleonemia scrupulosa Stål (Hemiptera: Heteroptera: Tingidae: Tinginae): ontogenetic features of integumentary structures highlighted. Zootaxa 3613(3):289-296.

Guilbert, E. 2004. Do larvae evolve the same way as adults in Tingidae (Insecta: Heteroptera)? Cladistics 20:139-150.

.2005. Morphology and evolution of larval outgrowths of Tingidae (Insecta, Heteroptera), with description of new larvae. Zoosystema 27(1):95-113.

Guilbert, E.; Desutter-Grandcolas, L. \& Grandcolas, P. 2008. Heterochrony in Tingidae (Insecta: Heteroptera): paedomorphosis and/or peramorphosis? Biological Journal of the Linnean Society 93(1):71-80.

Kormilev, N. A. 1955. A new myrmecophil family of Hemiptera from the delta of Rio Parana, Argentina. Revista Ecuatoriana de Entomologia y Parasitologia 2(3-4):465-477.

Livingstone, D. 1976. On the functional anatomy of the egg and the description of the nymphal instars of Dasytingis rudis Drake \& Poor (Heteroptera: Tingidae), a sap sucker on Vitex negundo (Verbenaceae). Journal of Natural History 10(5):529-544.

Mason, J. R.; Neal, J.; Oliver, J. E. \& Lusby, W. R. 1991. Bird-repellent properties of secretions from nymphs of the azalea lace bug author. Ecological Applications 1(2):226-230.

Montemayor, S. I. \& CARpintero, D. L. 2007. A new macropterous genus with a new species of Vianaididae (Heteroptera, Tingoidea, Vianaididae) from Peru. Studies on Neotropical Fauna and Environment 42(2):133-136.

Schun, R. T. \& Slater, J. A. 1995. True Bugs of the World (Hemiptera: Heteroptera), Classification and Natural History. Ithaca, Cornell University. 336p.

Schuh, R. T.; Cassis, G. \& Guilbert, E. 2006. Description of the first recent macropterous species of Vianaidinae (Heteroptera: Tingidae) with comments on the phylogenetic relationships of the family within the Cimicomorpha. Journal of the New York Entomological Society 114(1-2):38-53.

Souza-Silva, M.; Martins, R. P. \& Ferreira, R. L. 2011. Cave lithology determining the structure of the invertebrate communities in the Brazilian Atlantic Rain Forest. Biodiversity and Conservation 20(8): 1713-1729. 